\title{
Seed traits linked to differential survival of plants during the Cretaceous/Paleogene impact winter
}

\author{
KEITH BERRY \\ Science Department, Hoehne Re-3 School District, Hoehne, Colorado, 81046, USA; \\ e-mail: keith.berry@hoehnesd.org
}

Received 1 September 2020; accepted for publication 11 December 2020

\begin{abstract}
In past investigations the pattern of differential survival of plants across the K/Pg boundary has been viewed as incompatible with severe asteroid impact winter scenarios (i.e., an impact winter lasting more than a few months), particularly the enigmatic survival of coryphoid palms and Pandanus (screw pine). Stateof-the-art climate models based on soot, sulfate and nano-sized dust aerosols predict a global impact winter that drastically reduced precipitation and resulted in a transient period of total darkness and permafrost conditions. This suggests that the plants most likely to have been affected by the global mass-extinction event were tropical phanerophytes that produce recalcitrant seeds, which by definition are desiccation-intolerant, survive less than a year, and cannot survive freezing. However, this hypothesis has never been tested. In this study I sampled over 100 plant species from the global fossil record that have a high probability of having produced either recalcitrant seeds/disseminules $\left(n_{1}=58\right)$ or orthodox seeds $\left(n_{2}=59\right)$, based on their phylogenetic relationships with extant taxa that either are monomorphic for these traits or specifically exhibit a genetic marker for abscisic acid inhibition associated with seed dormancy and recalcitrance. A one-tailed z-test for the difference between two proportions revealed that plant taxa with a high probability of having produced recalcitrant seeds had significantly lower survivorship than plant taxa with a high probability of having produced orthodox seeds $(p<0.0001)$. Based on these data, it can be concluded that plants which formed a frost-tolerant seed bank during the latest Maastrichtian were significantly more likely to survive the K/Pg impact winter than plants which did not (including palms). These data clearly indicate that the K/Pg impact winter probably lasted longer than a year and that it selected for seed-based traits that effectively sorted correlated functional traits of mature plants (i.e., leaf physiognomic features). This novel hypothesis stands as an alternative to J.A. Wolfe's classic hypothesis that a mild K/Pg impact winter selected for fast-growing angiosperms with deciduous leaves and did not affect the plant communities of the Southern Hemisphere. Potential mechanisms for the rare survival of tropical, recalcitrant-seeded plants are discussed.
\end{abstract}

KEYWORDS: plants, mass extinction, K/Pg boundary, recalcitrant seeds, orthodox seeds

\section{INTRODUCTION}

The stratigraphic position of the Cretaceous/ Paleogene (K/Pg) boundary was first located with precision in terrestrial settings using the disappearance of Trisectoris Tschudy (Austrobaileyales) pollen in the Raton Basin of northeastern New Mexico in western North America (Tschudy, 1970). This fossil pollen is regarded to have been produced by plants closely related to extant Illicium L. and Schisandra Michx. (Tschudy, 1970; Upchurch et al., 2007). More than a decade later, the disappearance of this and other palynomorphs was linked to an iridium anomaly (Orth et al., 1981; Tschudy et al., 1984), which Alvarez et al. (1980) recognized as evidence of a large asteroid impact responsible for the K/Pg mass-extinction event. Eventually, the disappearance of Trisectoris pollen would be recognized as a high-resolution palynostratigraphic marker for the K/Pg boundary in eastern North America (Christopher and Prowell, 2002), and it would be discovered that dispersed cuticle and fossil wood attributed to 
Austrobaileyales also disappeared from the fossil record of the Raton Basin and Antarctica, respectively, at the K/Pg boundary (Upchurch, 1995; Poole and Cantrill, 2006).

Initial climate models based on the asteroid impact predicted an impact winter that lasted less than a year, based on the rapid settling time of dust aerosols produced by the impact event (Alvarez et al., 1982; Toon et al., 1982). Paleobotanists summarily accepted these models because the survival of thermophilic coryphoid palms (Arecipites columellus Leffingwell) and screw pine (Pandaniidites Elsik) seemed incompatible with an impact winter that lasted longer than a few months (Nichols et al., 1986; Tschudy and Tschudy, 1986; Nichols and Johnson, 2002), a perspective supported by the findings that palms characteristically exhibit frost-intolerant foliage, trunks, rootstock, seedlings and seeds (Greenwood and Wing, 1995; Hong et al., 1997). Initial reports on the viability of Sabal Adans. seeds, for example, suggested that these were short-lived (Crocker, 1938; Hofman and Steiner, 1989), and putative coryphoid palm seeds were among those first recognized to cross the K/Pg boundary in western North America (Fig. 1; Lesquereux, 1873; Ash and Tidwell, 1976). This interpretation was bolstered by the proposition that the dominant fern spore at the K/Pg boundary fern-spore spike was associated with the spores of a cyatheaceous tree fern, which also exhibits frost-intolerant foliage and short-lived spores (Upchurch et al., 2007; Spicer and Collinson, 2014 - but see Berry, in press).

Wolfe (1987) proposed that this mild impact winter selected for fast-growing angiosperms or the functional traits of mature plants (i.e., leaf physiognomic features associated with deciduousness), and this interpretation eventually was supported by leaf mass-per-unit area analyses (LMA; Royer et al., 2007) of the extensive fossil record of plants in western North America (Blonder et al., 2014; Lyson et al., 2019). Wolfe (1997) singled out Laurales as among the taxa most affected by the $\mathrm{K} / \mathrm{Pg}$ mass-extinction event. However, Wolfe's (1987) hypothesis cannot account for certain aspects of the plant fossil record, particularly the survival of slow-growing conifers (Brodribb et al., 2012), a pattern which Wolfe (1987) argued indicated that the Southern Hemisphere was not affected by the impact event. Furthermore, Wolfe (1987) argued that the K/Pg impact

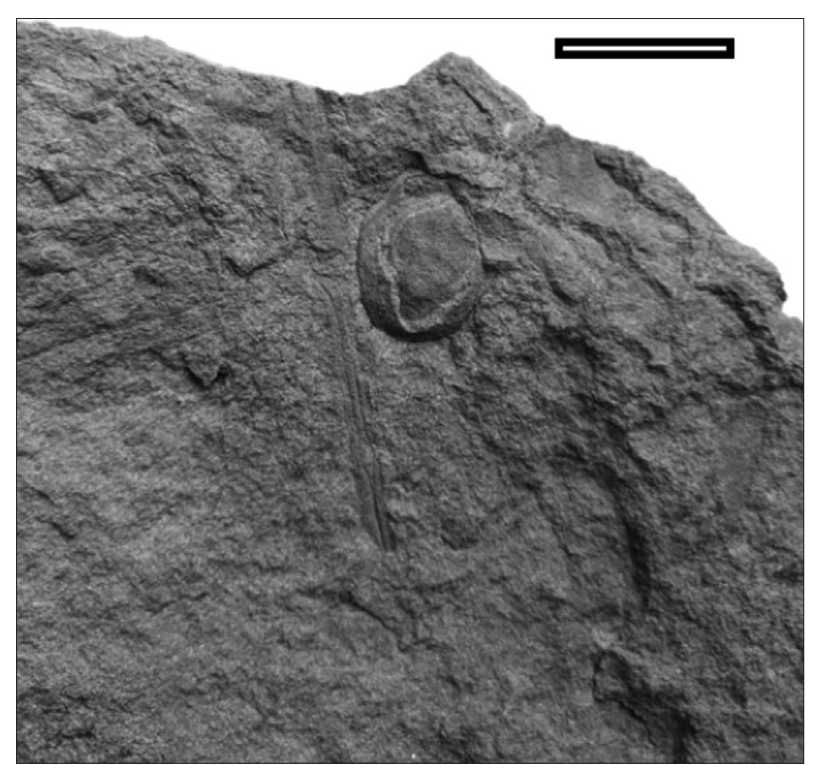

Fig. 1. Seed of Palmocarpon palmarum (Lesquereux) Knowlton, a species observed both below and above the K/Pg boundary. Scale bar $=2.5 \mathrm{~cm}$

winter affected only North America because of the rapid settling of dust aerosols before these had time to encircle the globe, a perspective that is now known to be incorrect (Vajda et al., 2001, 2015; Vajda and McLoughlin, 2004, 2007; Vajda and Bercovici, 2012, 2014; Stiles, et al. 2020). Otherwise, Wolfe (1987: 220) reasoned, the K/Pg impact winter would have to have lasted "several years." Spicer (1989) pointed out, however, that the extinction of broad-leaved evergreens seemed to make little sense in this context because these plants were perceived at the time to have seeds with viability greater than a decade and which therefore should have survived a mild impact winter that lasted only a few months.

Contemporary, state-of-the-art impact winter models predict an asteroid impact winter much more severe than that envisioned by the first-generation climate models of Alvarez et al. (1982) and Toon et al. (1982). In these second-generation models, stratospheric soot, sulfate and nano-sized dust aerosols produce an episode of global darkness that lasts slightly over a year, coupled with a drastic reduction in precipitation and a transient period of permafrost conditions in the interior of the continents (Vajda et al., 2015; Bardeen et al., 2017; Brugger et al., 2017; Chiarenza et al., 2020; Tabor et al., 2020). If these models are correct, then it is predicted that the plants most likely to have been affected by the K/Pg mass-extinction event were tropical plants with recalcitrant seeds, which by definition cannot survive longer 
than a year, cannot survive freezing, and are desiccation-intolerant (Roberts, 1973). This is because aboveground vegetation would have been destroyed by these severe climatic conditions (i.e., total darkness coupled with permafrost conditions) (Vajda and McLoughlin, 2004, 2007; Vajda and Bercovici, 2014), perhaps with a combination of syn- and post-impact wildfires caused by impact ejecta and the subsequent heat-pulse (Morgan et al., 2013). According to Subbiah et al. (2019), the vast majority (92\%) of plants with recalcitrant seeds are tropical phanerophytes - that is, large trees and shrubs that thrive in megathermal, equable climates with high precipitation/humidity (Huggett, 1998) that first evolved seed recalcitrance in response to global climatic conditions in the Late Cretaceous. To my knowledge, the hypothesis that recalcitrant-seeded plants were among those most affected by the $\mathrm{K} / \mathrm{Pg}$ impact winter has never been tested. However, it could explain why Austrobaileyales and Laurales were among the plant groups hit hardest by the K/Pg impact event in North America, as these taxa appear to exhibit the highest incidence of seed recalcitrance among angiosperms today (Wyse and Dickie, 2017).

\section{METHODS AND MATERIALS}

To test the hypothesis that plants with recalcitrant seeds suffered greater extinction than plants with longlived, desiccation- and frost-tolerant (orthodox; Roberts,
1973) seeds, I used two statistical tests on a global dataset of more than 100 plants (Tabs 1, 2). First, a onetailed Wilcoxon signed-rank test for matched pairs was used to determine whether recalcitrant-seeded plants experienced a significant reduction in species diversity/ richness across the $\mathrm{K} / \mathrm{Pg}$ boundary (Tab. 3). If species diversity of recalcitrant seeded-plants was unaffected by the event, then the Wilcoxon test would be expected to provide non-significant results (i.e., any reduction in standing species diversity across the $\mathrm{K} / \mathrm{Pg}$ boundary would be due to chance, and there would be no significant "before-and-after" reduction of species diversity as expected under the mild impact winter scenario). Second, a one-tailed z-test for the difference between two proportions was used to assess whether the proportion of plant species with recalcitrant seeds that survived the $\mathrm{K} / \mathrm{Pg}$ impact event was significantly lower than the proportion of plant species with orthodox seeds that survived the K/Pg impact event (Fig. 2). Because some plant groups predicted to be among the hardest hit by the K/Pg impact event, such as Laurales (Wolfe, 1997), are known to have diversified shortly after the $\mathrm{K} / \mathrm{Pg}$ event in both North America and South America (Northern and Southern Hemispheres) (Berry, 2019a, 2020; Stiles et al., 2020), these statistical analyses do not include species recognized from the early Paleocene recolonization flora unless these are known to have survived the impact event.

Species in this dataset were assigned either the recalcitrant or orthodox seed trait based on monomorphism of this trait among extant members of the same clades. Most assignments were based on studies conducted by Wyse and Dickie (2017) that used the Kew (Royal Botanic Gardens) Seed Information Database or other contemporary studies to determine the incidence of seed recalcitrance among extant taxa. Subbiah et al. (2019) recently studied the evolutionary lability of this trait through geologic time. They found that extant lineages with fossil records that extend into the Cretaceous first evolved this trait independently during

Table 1. Taxa with high probability of recalcitrant seeds or disseminules

\begin{tabular}{|c|c|c|}
\hline Taxon & Number of K/Pg survivors & Source \\
\hline Spinizonocolpites spp. (pollen) & $2 / 10$ & Raymer, 2010; Vallati et al., 2020 \\
\hline Nypa burtinii (fruit) & $1 / 1$ & El-Soughier et al., 2019 \\
\hline Austrobaileyales (cuticle) & $0 / 3$ & Upchurch, 1995 \\
\hline Trisectoris (pollen) & $0 / 2$ & Tschudy, 1970; Christopher and Prowell, 2002 \\
\hline Araucaria lefipanensis (leaf) & $0 / 1$ & Andruchow-Colombo et al., 2018 \\
\hline Araucaria spp. (cuticle) & $0 / 2$ & Pole and Vajda, 2009 \\
\hline Araucarioides (aff. Wollemia cuticle) & $0 / 1$ & Pole, 2008 \\
\hline Lauraceae (leaf and cuticle) & $4 / 20$ & $\begin{array}{l}\text { Kauffman et al., 1990; Johnson, 2002; Barclay et al., } \\
\text { 2003; Johnson et al., 2003; Berry, 2019a }\end{array}$ \\
\hline Lauraceae (cuticle) & $3 / 3$ & Pole and Vajda, 2009 \\
\hline Onoclea sensibilis (leaf) & $1 / 1$ & Barclay et al., 2003 \\
\hline Ginkgo (leaf) & $1 / 1$ & Manchester, 2014 \\
\hline Sassafrasoxylon gottwaldii (wood) & $0 / 1$ & Poole and Cantrill, 2006 \\
\hline Illicioxylon spp. (wood) & $0 / 2$ & Poole and Cantrill, 2006 \\
\hline Laurelites jamesrossii (wood) & $1 / 1$ & Poole and Cantrill, 2006 \\
\hline Tercissus spp. (pollen) & $1 / 4$ & Tschudy, 1970 \\
\hline Lauraceae (cuticle) & $0 / 1$ & Upchurch and Askin, 1990 \\
\hline \multirow[t]{2}{*}{ Lauraceae (leaf) } & $0 / 4$ & Stiles et al., 2020 \\
\hline & $14 / 58$ & \\
\hline
\end{tabular}


Table 2. Taxa with high probability of orthodox seeds

\begin{tabular}{l|c|l}
\hline \hline Taxon & Number of K/Pg Survivors & \multicolumn{1}{|c}{ Source } \\
\hline Sabal bracknellense / & $2 / 2$ & Manchester et al., 2010; Ash and Tidwell, 1976 \\
Palmocarpon palmarum (fruits) & $3 / 3$ & Greenwood and West, 2016 \\
Sabalites spp. (leaf) & $1 / 1$ & Srivastava et al., 2014 \\
Sabalites dindoriensis (leaf) & $1 / 1$ & Matsunaga et al., 2019 \\
Hyphaenocarpon (fruit) & $1 / 1$ & Nichols et al., 1986 \\
Arecipites columellus (pollen) & $1 / 1$ & Clarke, 1963; Manchester et al., 2010 \\
Sabalpollenites sp. (pollen) & $1 / 1$ & Johnson, 2002 \\
Cornophyllum newberryii (leaf) & $1 / 1$ & Johnson, 2002 \\
Nelumbium (leaf) & $1 / 1$ & Johnson, 2002 \\
Cupressinoxylon sp. (leaf) & $1 / 1$ & Johnson, 2002 \\
Folkieniopsis sp. (leaf) & $1 / 2$ & Johnson, 2002 \\
Glyptostrobus spp. (leaf) & $1 / 2$ & Johnson, 2002 \\
Metasequoia spp. (leaf) & $1 / 1$ & Johnson, 2002 \\
Taxodium sp. (leaf) & $0 / 1$ & Johnson, 2002 \\
Sequoia sp. (leaf) & $0 / 1$ & Johnson, 2002 \\
Cupressaceae indet. (leaf) & $1 / 1$ & Nichols and Johnson, 2002 \\
Taxodium (pollen) & $6 / 11$ & Johnson, 2002 \\
Cercidiphyllaceae spp. (leaf) & $2 / 2$ & Pole and Vajda, 2009; Escapa et al., 2018 \\
Agathis spp. (cuticle) & $1 / 1$ & Pole and Vajda, 2009 \\
Prumnopitys (cuticle) & $13 / 15$ & Leppe et al., 2012; Romero et al., 2019 \\
Nothofagiidites spp. (pollen) & $2 / 2$ & Vajda and Bercovici, 2014 \\
Banksia sp. (cuticle/pollen) & $1 / 1$ & Carpenter, 2005 \\
aff. Amborella (cuticle) & $6 / 6$ & Poole and Cantrill, 2006 \\
Nothofagoxylon spp. (wood) & $48 / 59$ & \\
\hline \multicolumn{2}{|l}{} &
\end{tabular}

Table 3. Wilcoxon signed-rank test for matched pairs $(z=-3.823, p=0.00007)$

\begin{tabular}{c|c|c|c|c|c|l}
\hline \hline K & Pg & Sign & Abs & $R$ & Sign $R$ & \multicolumn{1}{|c}{ Sources } \\
\hline 20 & 4 & 1 & 16 & 18 & 18 & Johnson, 2002; Barclay et al., 2003; Johnson et al., 2003 \\
6 & 0 & 1 & 6 & 15 & 15 & Upchurch, 1995 \\
8 & 1 & 1 & 7 & 16 & 16 & Upchurch, 1995 \\
3 & 0 & 1 & 3 & 11.5 & 11.5 & Upchurch, 1995 \\
1 & 0 & 1 & 1 & 4 & 4 & Tschudy, 1970; Pillmore et al., 1999 \\
3 & 0 & 1 & 3 & 11.5 & 11.5 & Johnson, 2002 \\
1 & 0 & 1 & 1 & 4 & 4 & Tschudy, 1970 \\
1 & 0 & 1 & 1 & 4 & 4 & Stone, 1973 \\
1 & 0 & 1 & 1 & 4 & 4 & Clarke, 1963 \\
1 & 1 & $\mathrm{n} / \mathrm{a}$ & 0 & $\mathrm{n} / \mathrm{a}$ & $\mathrm{n} / \mathrm{a}$ & Christopher and Prowell, 2002 \\
1 & 1 & $\mathrm{n} / \mathrm{a}$ & 0 & $\mathrm{n} / \mathrm{a}$ & $\mathrm{n} / \mathrm{a}$ & Nichols and Brown, 1992 \\
4 & 2 & 1 & 2 & 8.5 & 8.5 & Kauffman et al., 1990 \\
1 & 0 & 1 & 1 & 4 & 4 & Andruchow-Colombo et al., 2018 \\
3 & 0 & 1 & 3 & 11.5 & 11.5 & Pole, 2008; Pole and Vajda, 2009 \\
1 & 0 & 1 & 1 & 4 & 4 & Pole and Vajda, 2009 \\
1 & 1 & $\mathrm{n} / \mathrm{a}$ & 0 & $\mathrm{n} / \mathrm{a}$ & $\mathrm{n} / \mathrm{a}$ & Barreda et al., 2012 \\
3 & 3 & $\mathrm{n} / \mathrm{a}$ & 0 & $\mathrm{n} / \mathrm{a}$ & $\mathrm{n} / \mathrm{a}$ & Pole and Vajda, 2009 \\
11 & 3 & 1 & 8 & 17 & 17 & Raymer, 2010; El-Soughier et al., 2019; Vallati et al., 2020 \\
2 & 1 & 1 & 1 & 4 & 4 & Poole and Cantrill, 2006 \\
2 & 0 & 1 & 2 & 8.5 & 8.5 & Poole and Cantrill, 2006 \\
4 & 0 & 1 & 4 & 14 & 14 & Stiles et al., 2020 \\
4 & 1 & 1 & 3 & 11.5 & 11.5 & Tschudy, 1970 \\
1 & 0 & 1 & 1 & 4.5 & 4.5 & Upchurch and Askin, 1990 \\
\hline
\end{tabular}

the megathermal, equable climatic conditions of the late Cretaceous. The findings of Subbiah et al. (2019) are supported by contemporary perspectives on the evolution of seed recalcitrance, as the high moisture content of these seeds produced by tropical phanerophytes in megathermal, equable climates with high precipitation/humidity precludes their long-term survival of seeds under drying and freezing conditions (Hong et al., 1997; Wyse and Dickie, 2017).

Laurales, which in this study is regarded as producing recalcitrant seeds, is the only clade included in this study that does not exhibit monomorphism for 


\section{Selection for seeds across K/Pg boundary}

$99 \%$ confidence interval for difference betweeen two proportions

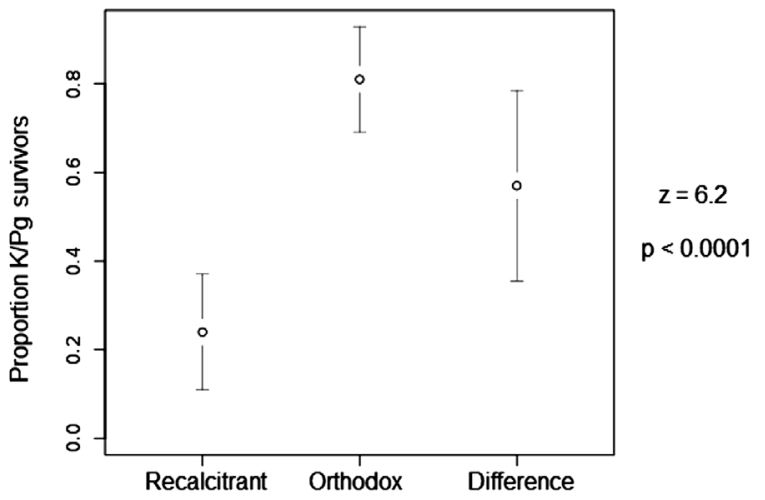

Fig. 2. One-tailed z-test for the difference between two proportions reveals that plant taxa with a high probability of exhibiting recalcitrant seeds experienced significantly greater extinction across the $\mathrm{K} / \mathrm{Pg}$ boundary than plant taxa with a high probability of exhibiting orthodox seeds $(p<0.0001)$.

seed recalcitrance among its extant members (Wyse and Dickie, 2017; Jaganathan et al., 2019). The reason for including this clade in this study is that Chen et al. (2020) recently identified an autapomorphic genetic marker for abscisic acid-inhibition associated with seed recalcitrance among the species in this clade; in accordance with the perspective of Subbiah et al. (2019), therefore, it appears that lauraceous species evolved this trait during the late Cretaceous, because this genetic marker appears to be shared among all sampled genera in this clade, regardless of whether this gene is currently expressed among all of these genera (e.g., Jaganathan et al., 2019). Interestingly, this mechanism behind recalcitrant seeds (i.e., genetically based transcription factors that regulate abscisic acid inhibition) is widely recognized as being the general cause of seed recalcitrance in most plants included in this study (Farnsworth, 2000), particularly Austrobaileyales (Smiskova et al., 2005) and Laurales (Chen et al., 2020). The study done by Subbiah et al. (2019) demonstrated that orthodoxy among these lineages evolved in the cooler, drier climates of the Cenozoic, so it is clear that recalcitrance among lauraceous species is the ancestral condition in this group. It is difficult to assign fossil species to Lauraceae exclusively; that is why most often these species are conservatively assigned to Laurales only (Upchurch, 1995; Pole and Vajda, 2009). Lauraceous or lauraceous-like plants have been reported from multiple $\mathrm{K} / \mathrm{Pg}$ boundary localities across the Northern and Southern Hemispheres (Wolfe and Upchurch, 1987; Kauffman et al., 1990; Upchurch and Askin, 1990; Upchurch, 1995; Wolfe, 1997; Johnson, 2002; Barclay et al., 2003; Johnson et al., 2003; Poole and Cantrill, 2006; Pole and Vajda, 2009; Stiles et al., 2020). Hence, the global distribution of this clade during the Late Cretaceous can be used to test the hypothesis that the K/Pg boundary impact winter had global effects.

The dataset utilized in this study is comprised of more than 100 fossil species based on pollen, leaf/cuticle, fruit and wood records from North America, South America, Africa, Antarctica, New Zealand and India.
One of the major challenges faced by this study is the relatively small sample size. Seed recalcitrance and orthodoxy are not easily assigned to fossil taxa because these traits cannot be observed directly, which limits the number of possible comparisons that can be drawn. I assign these traits to fossil species primarily through phylogenetic inference based on the incidence of these traits among extant members of the same clade. This raises the question of evolutionary lability in these traits, particularly among groups that are dimorphic for these characters. For that reason, I focus primarily on monomorphic clades, which further limits the number of comparisons that can be drawn between extinct and extant taxa. It is possible to assess whether there is a strong phylogenetic signal using the discrete character distribution among extinct taxa within a late Cretaceous clade, as I have previously demonstrated for chasmosaurine ceratopsid dinosaurs (Berry, 2018a), but these techniques require that the discrete character distribution be mapped to a preexisting phylogeny and that there be dimorphism in these states. In most cases there is no known phylogeny that incorporates both extinct and extant members of these clades, although there are a few examples (e.g., Andruchow-Colombo et al., 2018; Escapa et al., 2018 - both of which informed this study), and the discrete character states of only some extant and no extinct taxa are known (Wyse and Dickie, 2017). Furthermore, there is debate as to whether nodes in such analyses should exhibit a single discrete character state or be dimorphic for these seed traits - alternative interpretations based on the researcher's preference for the type of parsimony used during phylogenetic inference (Berry, 2018a). In other words, researchers can arbitrarily choose between parsimony schemes that permit either dimorphic discrete character states in common ancestors (separate individuals or populations of common ancestors exhibit both discrete character states) or only a single trait (discrete character states are mutually exclusive among species) based on a priori assumptions about the nature of these traits (Berry, 2018a). For all of these reasons, such methods are inappropriate for the task at hand. Moreover, this difficult task is complicated by an unknown amount of extinction in the clades under investigation. In some cases, such as nypoid palms and Ginkgo, there is but a sole survivor with which to compare numerous extinct taxa. This is why in this study I rely on the results of other researchers who have focused solely on extant taxa for which there is reasonable evidence that these traits are conservative in certain taxonomic categories or at certain levels of taxonomy (e.g., Wyse and Dickie, 2017; Subbiah et al., 2019; Chen et al., 2020). Due to the recent extensive work by Subbiah et al. (2019) on this topic, I presume that seed recalcitrance arose among these extant lineages in the late Cretaceous and therefore was present in these lineages prior to the endCretaceous mass-extinction event. However, I acknowledge the inherent element of uncertainty in the determination of these seed traits among extinct taxa and recognize that these extinct taxa merely seem to exhibit a high probability of having had these traits, based on contemporary taxonomic concepts (i.e., comparison with their closest living relatives). To circumvent the issue of dimorphism, which may lead to problems of evolutionary lability within or among extinct groups, I have 
focused almost exclusively on plant groups that appear monomorphic for the traits in question.

Wyse and Dickie (2017) observed that $98.6 \%$ of all extant genera included in their study were monomorphic for orthodox seeds; recalcitrance is observed among only $1.4 \%$ of the extant genera included in their analysis, which suggests that this trait is generally rare. It has been demonstrated that seed recalcitrance was more frequent in the globally megathermal climates of the late Cretaceous than in the cooler, drier climates of the present (Subbiah et al., 2019); however, the present study focused almost exclusively on clades that exhibit monomorphism for recalcitrance or orthodoxy, to avoid ambiguity. Many of the so-called "hot spots" for seed recalcitrance among the clades identified in the study by Wyse and Dickie (2017) are also incorporated in this study, including Austrobaileyales, Laurales, Arecales and Araucaria sections Bunya, Intermedia and Araucaria. Ginkgo and Onoclea sensibilis L. are assigned recalcitrance based on studies of these extant taxa specifically (Lloyd and Klekowski, 1970; Tommasi et al., 2006).

To avoid issues related to taphonomic bias or differences in preservation, I have attempted to include fundamentally different types of fossils in this analysis (pollen, leaves/cuticle, fruits and wood). A potential problem with this approach is that species concepts may overlap (e.g., coeval pollen may have been produced by one or more surviving species that are recognized as foliage; Berry, 2019a; Berry, in press); however, due to the differences in taphonomic pathways exhibited among these various types of fossils, this "overlap" in species concepts is probably minimal, particularly as wind-blown palynomorphs are generally interpreted as being representative of species in the broader catchment area of a regional depositional setting (facies-independent fossils), whereas megafossils are generally regarded to be representative of species in a local depositional setting (facies-dependent fossils) (Berry, in press). In other cases, such as in the case of nypoid palms, for example, the geographic distribution of known fossil fruits and pollen are disparate (El-Soughier et al., 2019; Vallati et al., 2020), so this effect probably is negligible. The only fossils included in this study for which there might be significant overlap in species concepts among various types of organs include fossils of Sabalites pollen, fruit and foliage (Manchester et al., 2010). However, this inference is based primarily on co-occurrence of fossils, which can be misleading (Berry, in press). In turn, this perspective is balanced by the fact that some fossils, such as pollen/fruit, are either known to have been or are suspected of having been produced by more than one leaf-based taxon through geologic time (Manchester et al., 2010; El-Soughier et al., 2019; Berry, in press). In summary, inclusion of these various types of fossils in the present dataset is meant to accommodate the fact that extinction at the $\mathrm{K} / \mathrm{Pg}$ boundary might only be apparent due to chance preservation because of taphonomic factors (e.g., rarity of pollen, leaves/cuticle, fruits or wood).

Rare occurrences of some fossils, such as pollen, in the earliest Danian are included in the present study although they might be reworked (e.g., Nichols and Brown, 1992).
Another challenge facing this study is disagreement over whether seed recalcitrance or orthodoxy was the ancestral condition among angiosperm clades that first arose during the early Cretaceous (Tweddle et al., 2003; Villegente et al., 2017), because this study deals directly with fossil representatives of these groups (e.g., Wolfe and Upchurch, 1987; Upchurch, 1995). At the time that they conducted their study, seed traits of Amborellales were unknown to Wyse and Dickie (2017). However, it is now known that this group displays traits associated with orthodox seeds (Villegente et al., 2017). Therefore it is clear that seed recalcitrance among some of these basal angiosperms, such as in extant Austrobaileyales, is a derived condition that emerged after the origin of basal angiosperms in the early Cretaceous during the megathermal, equable climate of the late Cretaceous (Subbiah et al., 2019). According to Carpenter (2005), at least one example of Amborella or an Amborella-like taxon (Amborellales) is known to have crossed the $\mathrm{K} / \mathrm{Pg}$ boundary. This ancestral angiosperm taxon may have been closely related to other basal angiosperm taxa resembling Austrobaileyales, which also first emerged in the early Cretaceous (e.g., Upchurch, 1995); however, the recalcitrant seed trait does not appear to have evolved until the late Cretaceous with the appearance of taxa more closely resembling extant Austrobaileyales (e.g., Illicium and Schisandra) (Subbiah et al., 2019). That is why this basal angiosperm taxon is assigned to the orthodox seed category in the present study, based on these cuticle studies in combination with new data on their seed traits (e.g., Capenter, 2005; Villegente et al., 2017; Subbiah et al., 2019), although Wyse and Dickie (2017) lacked the information necessary to assign seed traits to Amborellales.

In view of the attention specifically given to palms in the debate over whether the fossil record of plants accords with severe impact winter models (Nichols et al., 1986; Nichols and Johnson, 2002), this study intentionally addresses the fossil record of palms with characteristically different seed traits. Although Arecales is recognized as one of the "hot spots" for seed recalcitrance in a study by Wyse and Dickie (2017), this trait is not uniformly distributed among the clades in this group. There is a large body of data indicating that coryphoid palms in particular, such as Sabal, Serenoa, Hyphaene and others, characteristically produce orthodox seeds (Carpenter, 1987; Dickie et al., 1993; Hong et al., 1997; Davies and Pritchard, 1998; Dickie and Pritchard, 2002; Orozco-Segovia et al., 2003; Wood et al., 2006; Barbour, 2008; Olson, 2008). Sabalites palms in western North America and in India during the $\mathrm{K} / \mathrm{Pg}$ transition are known to have produced Sabal and Hyphaene-type fruits (Manchester et al., 2010; Srivastava et al., 2014; Matsunaga et al., 2019). In view of that, these taxa are regarded as orthodox in the present study (e.g., all members of Sabal are known to produce orthodox seeds; Carpenter, 1987; Olson, 2008). On the other hand, nypoid palms (i.e., Nypa) are known to exhibit recalcitrant seeds (Farnsworth, 2000). This discrepancy has been explained previously by the differences in climatic tolerance of coryphoid versus nypoid palms (Hong et al., 1997), which are known to have distinctly different climatic distributions (Reichgelt et al., 2018). Nypa 
is among the most tropical of palms, with a lower cold month mean temperature (CMMT) tolerance of $\sim 17^{\circ} \mathrm{C}$, whereas coryphoid palms (e.g., Sabal) are among the least tropical of palms, with a CMMT tolerance of $\sim 5^{\circ} \mathrm{C}$ (Reichgelt et al., 2018). Thus, nypoid palms are prone to produce recalcitrant seeds because of their presence in tropical, equable climates with high precipitation/humidity, whereas coryphoid palms are prone to produce orthodox seeds because of their presence in cooler, drier climates (Hong et al., 1997; Wyse and Dickie, 2017). Nypa fruits are known from $\mathrm{K} / \mathrm{Pg}$ boundary strata in equatorial Africa (El-Soughier et al., 2019), although a diverse pollen assemblage produced by nypoid palms is known throughout the Southern Hemisphere during this time (Raymer, 2010; Vajda and Bercovici, 2012; Vallati et al., 2020).

The most dubious taxonomic assignments in this study involve putative coryphoid palm pollen and fruits, such as Arecipites columellus and Palmocarpon palmarum (Lesquereux) Knowlton (syn. P. commune (Lesquereux) Lesquereux) (Harley, 2006; Upchurch et al., 2007; Manchester et al., 2010). The pollen of A. columellus has classically been attributed to that of a palmetto-like coryphoid palm (Frederiksen, 1980; Raymond et al., 1997), but some researchers have questioned this interpretation (Upchurch et al., 2007; Manchester et al., 2010). When Lesquereux (1873: 391) first described $P$. palmarum fruits, he specifically described these as the fruits of "Sabal" campbelli Newberry, a taxon that Dorf (1939) later synonymized with Sabalites ungeri (Lesquereux) Dorf. However, $S$. ungeri foliage was later found associated with Sabal bracknellense (Chandler) Mai fruits (Manchester et al., 2010). My investigations in the Lower Paleocene strata of the Raton Formation suggest that $P$. palmarum fruits are also commonly associated with Sabalites tenuirachis (Lesquereux) Read et Hickey foliage as well as that of $S$. ungeri (Berry, 2018b, 2020). According to Lee and Knowlton (1917) and Ash and Tidwell (1976), the fruits of $P$. palmarum have been collected from Upper Maastrichtian strata (Vermejo and basal Raton formations) in the Raton Basin and are commonly associated with Sabalites foliage. Lee and Knowlton (1917: 192) also described one specimen from Wyoming that was collected from "inside a large dinosaurian bone." Thus, there appears to be abundant evidence that $P$. palmarum crossed the $\mathrm{K} / \mathrm{Pg}$ boundary in the Raton Basin and other regions in western North America. The interpretation that Palmocarpon fruits described from this region probably were produced by palmetto-like coryphoid palms, which began with Lesquereux (1873), has been reiterated numerous times in the literature (e.g., Berry, 1922; Knowlton, 1930; Su et al., 2019), but this has not been verified by analyses of diagnostic morphological characters (Brown, 1962; Harley, 2006; Manchester, 2014; Huegele and Manchester, 2020).

Extinct araucarian conifer fossils from North America, New Zealand and South America are most often allied with extant Araucaria Sections Bunya, Intermedia and Araucaria or with Wollemia (Johnson, 2002; Pole, 2008; Andruchow-Colombo et al., 2018). These extant taxa produce recalcitrant seeds (Hong et al., 1997; Offord et al., 1999). That is why Wyse and Dickie (2017) recognized these regions as "hot spots" for seed recalcitrance. In contrast, Agathis (an araucarian conifer) and Prumnopitys (a podocarp), which are also found in the $\mathrm{K} / \mathrm{Pg}$ boundary strata of New Zealand and South America (Pole and Vajda, 2009; Escapa et al., 2018), characteristically exhibit orthodox seeds (Whitmore, 1980; Bowen and Whitmore, 1980; Clout and Tilley, 1992; Dickie and Smith, 1995). Cupressaceous conifers universally produce orthodox seeds (Hong et al., 1997; Dickie and Pritchard, 2002), as does Banksia (based on an analysis of the Kew Seed Information Database: Wyse and Dickie, 2017).

Among the taxa in this study, Nelumbium is the taxon with the longest-lived seeds known, as these seeds live longer than a millennium (Shen-Miller et al., 1995; Shen-Miller, 2002). This taxon is known to have crossed the $\mathrm{K} / \mathrm{Pg}$ boundary in southwestern North Dakota (Johnson, 2002). Although many plant taxa in this study have been classified as having produced orthodox seeds, the maximum viability of many of these seeds is unknown. The results of all of these investigations of seed longevity/viability are listed in Tables 1 and 2 .

\section{DATA AND RESULTS}

The one-tailed Wilcoxon signed-rank test for matched pairs revealed a significant reduction in the standing species richness/diversity of recalcitrant-seeded plant taxa across the K/ Pg boundary (Table $3 ; \mathrm{p}=0.00007$ ). The twosample z-test for a difference in proportions revealed that plant taxa with a high probability of exhibiting recalcitrant seeds based on phylogenetic inference had a significantly lower proportion of survivor species than those plant taxa with a high probability of having orthodox seeds based on phylogenetic inference (Fig. 2; $\mathrm{z}=6.2, \mathrm{p}<0.0001$ ). Nypoid palms appear to have experienced greater turnover than coryphoid palms did, but the sample sizes are too small to test this hypothesis directly outside of the context of the broader patterns exhibited in the dataset.

\section{DISCUSSION}

These results clearly indicate that plants that had a high probability of producing recalcitrant seeds based on phylogenetic inference (i.e., monomorphic character states associated with extant members in these clades) suffered significantly greater extinction at the $\mathrm{K} / \mathrm{Pg}$ boundary than did plants that had a high probability of producing orthodox seeds based on phylogenetic inference. Because this 
study included a diverse assemblage of more than 100 species from both the Northern and Southern Hemispheres, I regard this pattern as compelling evidence that the $\mathrm{K} / \mathrm{Pg}$ massextinction event selected against plants with recalcitrant seeds on a global scale. Turnover among tropical taxa even in equatorial regions, such as Spinizonocolpites-producing nypoid palms (Raymer, 2010), has been well documented, so there appears to have been very limited refugia for these tropical plants at the $\mathrm{K} / \mathrm{Pg}$ boundary.

This distinct pattern implies that contemporary asteroid impact winter models, which predict an impact winter lasting longer than a year, coupled with extreme desiccation ( $\sim 85 \%$ reduction in precipitation according to Chiarenza et al., 2020) and a transient episode of permafrost conditions (Chiarenza et al., 2020; Tabor et al., 2020), probably are correct. Such an interpretation is bolstered by the perspective that high-latitude regions in the Southern Hemisphere, such as Patagonia, Argentina, were once regarded as refugia for plants during the $\mathrm{K} / \mathrm{Pg}$ mass-extinction event (Barreda et al., 2012), although this changed when Stiles et al. (2020) discovered evidence of a megafloral mass-extinction event of approximately the same magnitude ( $90 \%$ of species) and nature (destruction of broadleaved evergreen forests, resulting in leaf physiognomicbased drops in mean annual temperatures of $-5^{\circ} \mathrm{C}$ ) as that described from western North America by Johnson (1996, 2002), Wilf et al. (2003) and Wilf and Johnson (2004). Although these discoveries are new, they were nonetheless predicted by Iglesias et al. (2011) following the description of an early Paleocene megafloral assemblage (Iglesias et al., 2007).

The traits described in this study (seed recalcitrance and orthodoxy) are associated with the ecological dynamics of tropical plant communities. Tropical climax vegetation typically produces recalcitrant seeds, whereas tropical pioneer species characteristically produce orthodox seeds (Tweddle et al., 2003; Wyse and Dickie, 2017). This presumably explains many of the more enigmatic aspects of the patterns of plant succession across the $\mathrm{K} / \mathrm{Pg}$ boundary, such as why Agathis characteristically replaced other araucarian conifers with a stronger resemblance to Araucaria Sections Bunya, Intermedia and Araucaria or Wollemia in both New Zealand and South America (Pole and Vajda, 2009; Escapa et al., 2018), although podocarps, which apparently have a high incidence of recalcitrant seeds (Wyse and Dickie, 2017), eventually rose to dominance (Pole and Vajda, 2009). Similarly, lauraceous species along with non-magnoliid "dicot" angiosperms suffered considerable extinction in Patagonia, although they quickly returned to dominance (Stiles et al., 2020), a pattern also observed about ten thousand kilometers to the north in the Raton Basin of the southern Western Interior of North America (Berry, 2019a). Because there was obviously little or no biogeographic continuity between these regions, these similar biogeographic patterns must be due to fundamental rules of tropical plant community assembly (i.e., ecological succession following an environmental catastrophe). Without this context, the pattern of conifer succession across the $\mathrm{K} / \mathrm{Pg}$ boundary has been described as enigmatic (Pole and Vajda, 2009).

Overprinted on this general pattern of recovery is recolonization of South America by orthodox seed-producing Nothofagus from Antarctica (Leppe et al., 2012; Jud et al., 2018; Romero et al., 2019). Climate models clearly indicate that the polar regions offered no climatic refugia for the mature forms of such plants (Chiarenza et al., 2020), so it is clear from the present data that these plants must have recovered from a seed bank. This is consistent with the global trend, outlined for the first time in this paper (Fig. 2).

A wealth of contemporary biogeographic data supports the interpretation that extant New World Austrobaileyales and Laurales are derived from Old World progenitors and that vicariance between the Old and New World floras post-dates the Cretaceous (Chanderbali et al., 2001; Denk and Oh, 2006; Morris et al., 2007; Nie et al., 2007; Li et al., 2011). Based on my work, I recognize only four possible lauraceous species (leaf/cuticle-based taxa) from Johnson's (2002) study that survived the K/ $\mathrm{Pg}$ mass-extinction event in western North America (Berry, 2019a). Except for Kauffman et al. (1990), Barclay et al. (2003) and Johnson et al. (2003), prior studies seemed to indicate that lauraceous taxa were all but extinguished from western North America at the K/Pg boundary (Upchurch, 1995; Wolfe, 1997; Johnson, 2002). Following the K/Pg massextinction event, a number of taxa superficially resembling extant lineages of Laurales 
first appear in the early Paleocene in western North America (e.g., Persea-like, Sassafraslike and Lindera-like plants) (Brown, 1962; Manchester, 2014). As these are more likely representative of extant lineages than are the handful of relict, extinct forms that survived the $\mathrm{K} / \mathrm{Pg}$ mass-extinction event in western North America (e.g., "Artocarpus" lessigiana; Kauffman et al., 1990), it is conceivable that they may have colonized this region from more northern latitudes, a hypothesis consistent with contemporary biogeographic concepts (Wolfe, 1975; Tiffney and Manchester, 2001). Stiles et al. (2020) also observed that lauraceous species in the Lower Paleocene strata of South America were not identical to species present before the K/Pg event.

Survival of recalcitrant-seeded tropical plant taxa in the context of a severe global impact winter remains enigmatic. That these taxa survived at all remains a major conceptual hurdle which contemporary climate models must overcome before they can be widely accepted. However, there are clues as to how these taxa might have survived such an event. Nypa palms, for example, are known to exhibit long-distance dispersal by ocean currents (Noblick et al., 2018), a phenomenon that has been described to have occurred with fruits at the K/Pg boundary (El-Soughier et al., 2019). Ocean temperatures along the equator are projected to have remained relatively warm when compared to continental landmasses on the equator, due to the thermally insulating properties of seawater along this region (Chiarenza et al., 2020); this means that drift seeds probably survived the extreme cold experienced by continental settings during the $\mathrm{K} / \mathrm{Pg}$ impact event. However, the short-term viability of Nypa drift seeds might be problematic in the context of global darkness that lasted longer than a year (e.g., Bardeen et al., 2017; Tabor et al., 2020). Nypa palm seeds are known to drift long distances, but these typically show only $\sim 10 \%$ viability upon arrival at these distant sites (Noblick et al., 2018). Because of their recalcitrant nature, many of these few surviving seeds germinate during oceanic transport (Noblick et al., 2018). Single seedlings have been documented to give rise to viable, rapidly spreading populations within a matter of decades, through a combination of clonal reproduction and cross-pollination within these local populations (Noblick et al., 2018). Species selection could explain the apparently high diversity of nypoid palm pollen in the geologic past because of such frequent founder events (Futuyma, 1989; Jablonski, 2008). Once they have germinated, Nypa typically take about three to five years to mature (Snedaker and Getter, 1985). The combination of these traits (short-duration seed viability coupled with rapid maturity in three to five years) suggests that, in the low-resolution stratigraphic record, recolonization of landscapes by nypoid palms should appear instantaneous in the palynological record. This seems to be the case, as the base of the Spinizonocolpites baculatus Zone marks the K/Pg boundary throughout the Southern Hemisphere (Vajda and Bercovici, 2012; Vallati et al., 2020).

On the other hand, recolonization of western North American landscapes by Arecipites columellus-producing palmetto-like coryphoid palms appears to have been delayed by about half a millennium or longer. This interpretation is based on the estimated amount of time to produce $\sim 1 \mathrm{~cm}$ of coal according to McIver (1999), coupled with other chronostratigraphic constraints presented by Lyson et al. (2019), such as the age of the base of the Momipites tenuipolus Zone relative to the age of the $\mathrm{K} /$ Pg boundary (Renne et al., 2018). In western North America, A. columellus pollen does not instantaneously reappear above the K/Pg boundary (Upchurch, 1995; Nichols and Johnson, 2002). At Sugarite, this occurs $\sim 7 \mathrm{~cm}$ above the K/Pg boundary (Upchurch, 1995). Cuticle and palm megafossils (foliage and putative drupes) reappear $\sim 0.15-0.6 \mathrm{~m}$ above the $\mathrm{K} / \mathrm{Pg}$ boundary (Lee and Knowlton, 1917; Upchurch, 1995; Pillmore et al., 1999). This longer timescale is proportional to the longevity of these palms, which may persist for several centuries as individuals (Zona, 1990; Takahashi et al., 2011), or as clonally derived genets for $\sim 10$ ky or longer (Takahashi et al., 2011). The latter value is consistent with the reappearance of $A$. columellus in the Great Plains region of western North America tens of centimeters above the K/Pg boundary (Nichols and Johnson, 2002).

Along with the coryphoid palm pollen of Arecipites columellus, Nichols et al. (1986) and Nichols and Johnson (2002) argued that the survival of thermophilic plants that produce Pandaniidites pollen is inconsistent with a severe $\mathrm{K} / \mathrm{Pg}$ impact winter scenario. As with 
coryphoid palms, however, Pandanus is known to produce orthodox seeds (Franchi et al., 2011). Wolfe (1997) questioned whether Pandaniidites was produced by Pandanus. Similarly, there is discussion as to whether A. columellus might have been produced by plants other than palms (Upchurch et al., 2007; Manchester et al., 2010).

Survival of Onoclea sensibilis (a warmtemperate to temperate fern) and Ginkgo can be explained by frost-tolerant belowground reserves. Fossil $O$. sensibilis is essentially indistinguishable from the living species (Rothwell and Stockey, 1991), as is fossil Ginkgo (Brown, 1962). O. sensibilis exhibits among the highest investment in belowground biomass observed among extant ferns (Britton and Watkins, 2016), and these rhizomes can survive temperatures higher than $-17.5^{\circ} \mathrm{C}$ (Sato, 1982). Ginkgo similarly produces hysteresis (antifreeze) proteins (Duman and Olsen, 1993) and rhizome-like basal chichi, which have already been implicated in the survival of this taxon across the K/Pg boundary (Tredici, 1992), so the survival of these more temperate taxa with recalcitrant disseminules is not unexpected.

In summary, there is strong evidence that tropical plant taxa with recalcitrant seeds suffered greater extinction at the K/Pg boundary than did plant taxa that formed a frost-tolerant seed bank. J.A. Wolfe (1987) originally proposed that a mild K/Pg impact winter, like that described in climate models by Alvarez et al. (1982) and Toon et al. (1982), selected for fastgrowing angiosperms with deciduous leaves over slow-growing evergreens. This hypothesis was framed primarily around a study by Wolfe and Upchurch (1987) in the Raton Basin of northeastern New Mexico and southern Colorado, where Tschudy (1970) first identified the $\mathrm{K} / \mathrm{Pg}$ boundary in terrestrial sections using the disappearance of Austrobaileyales pollen. Although studies of Johnson's (2002) extensive leaf dataset and the plant fossil record in the Denver Basin appear to support Wolfe's (1987) hypothesis (Blonder et al., 2014; Lyson et al., 2019), Wolfe (1987) did not anticipate that the K/Pg impact winter lasted longer than a year, because at the time of his investigation the Southern Hemisphere appeared not to have been affected by this event. In Wolfe's (1987: 220) words:

The striking difference between the Northern and Southern Hemispheres in diversity of broad-leaved deciduous plants during the Paleocene and Eocene strongly suggests that the 'impact winter' had little effect on the land flora of the Southern Hemisphere, as does the persistence of evergreen conifers in mesothermal and megathermal Southern Hemisphere vegetation. Assuming that the terminal Cretaceous event resulted in an 'impact winter' (Alvarez et al., 1982), the duration of the sunlight-attenuating cloud must have been brief, perhaps a few to several months. Had the debris that caused the 'impact winter' remained in the atmosphere for several years, much debris would have entered the Southern Hemisphere atmosphere; as in the Northern Hemisphere, Southern Hemisphere mesothermal and megathermal vegetation should have displayed the effects of an 'impact winter' through the Paleocene and Eocene. A brief duration of the impact winter' is consistent with other paleobotanical and paleozoological data.

It is now understood that the Southern Hemisphere experienced a megafloral massextinction event on the same scale or magnitude as that observed in the Northern Hemisphere (Pole and Vajda, 2009; Stiles et al., 2020), and this discovery necessitates a reconsideration of Wolfe's (1987) classic hypothesis in light of an impact winter that lasted "several years" (Wolfe, 1987: 220). Furthermore, the paleozoological data also appear consistent with an impact winter that lasted several years (Chin et al., 2013; Robertson et al., 2013; Chiarenza et al., 2020). As Wolfe (1987) recognized that his hypothesis could not account for turnover among predominately evergreen conifer communities in the Southern Hemisphere, it must be recognized that the findings of Blonder et al. (2014) and Lyson et al. (2019) which appear to support Wolfe's (1987) hypothesis are probably better understood as selection for seed ecology rather than as selection for the functional traits of mature plants (i.e., leaf physiognomy). Broadleaved evergreens characteristically produce recalcitrant disseminules (Tweddle et al., 2003; Wyse and Dickie, 2017; Subbiah et al., 2019), so selection for or against these seed traits will inherently sort correlated traits associated with the mature plant developed from the seed via the hitchhiking effect of developmentally (ontogenetically) correlated characters described by Vrba and Gould (1986). A severe impact winter like that at the $\mathrm{K} / \mathrm{Pg}$ boundary must have precluded selection for leaf-based traits by effectively killing practically all aboveground vegetation (Vajda and McLoughlin, 2004, 2007; Field 
et al., 2018); this means that these leaf-based traits must have been sorted by selection for plants that formed a frost-tolerant seed bank, which happened to include plants adapted to cooler and drier climates, as the incidence of seed recalcitrance decreases from the equator to the poles (e.g., Tweddle et al., 2003; Wyse and Dickie, 2017). The survival of plant taxa with predominately orthodox seeds (e.g., Cornales) is consistent with the early Paleocene carpoflora of the Denver Basin (Huegele and Manchester, 2020).

Some recalcitrant-seeded tropical plants obviously survived the K/Pg event. This might be attributable to the fact that recalcitrance and orthodoxy are merely two extremes along a spectrum or continuum of traits related to seed dormancy (Ellis et al., 1990; Dickie and Smith, 1995). For the sake of simplicity, Tweddle et al. (2003) and Wyse and Dickie (2017) grouped such seeds with "intermediate" or "sub-orthodox" desiccation and freezing tolerance (sensu Ellis et al., 1990 and Dickie and Smith, 1995, respectively) with orthodox seeds. It is easy to envision a situation wherein locally adapted populations at the northern or southern limits of a tropical species' range exhibit such intermediate seed traits, although the present study does not address this complicating factor. In any case, a minor percentage of such intermediate seeds can survive for several years under freezing conditions (Dickie and Smith, 1995). This is all that might have been required for a tropical species to survive, which could explain the genetic contiguity between New World lauraceous and Austrobaileyales floras with boreotropical floras during the Paleogene and Neogene. Perhaps locally adapted populations with slightly more orthodox seed behaviors preferentially survived the mass-extinction event, although this would not be captured in a study focused solely on discrete characters (i.e., extremes on the spectrum). Based on the available evidence, I suggest that the overall pattern of survival is consistent with selection for tropical plant taxa that survived on the margins of their range. This is bolstered by the interpretation that many extant lauraceous species are on the border of recalcitrant/intermediate in terms of seed behavior, including some of those that are superficially similar to those that first appear in western North America slightly above the K/Pg boundary (e.g., Jaganathan et al., 2019).

\section{CONCLUSION}

A global pattern of differential plant survival across the $\mathrm{K} / \mathrm{Pg}$ boundary can be linked to fundamental differences in seed ecology. Plants that preferentially survived the K/ $\mathrm{Pg}$ mass-extinction event produced orthodox seeds, which permitted the formation of a frost-tolerant seed bank that ensured their survival over several years until favorable climatic conditions returned. These data support contemporary state-of-the-art impact winter models and provide an explanation for the selective nature of the $\mathrm{K} / \mathrm{Pg}$ impact event on plant assemblages that is more general than J.A. Wolfe's classic hypothesis. Seed ecology appears to explain a number of features of the $\mathrm{K} / \mathrm{Pg}$ boundary plant record that either were enigmatic or were once regarded as incompatible with severe asteroid impact scenarios.

\section{ACKNOWLEDGMENTS}

I thank Miranda and Tell Berry for their support for this project. I also thank Vivi Vajda, an anonymous reviewer and the editors for their assistance in greatly improving the quality and focus of the paper.

\section{REFERENCES}

Alvarez, L.W., Alvarez, W., Asaro, F., Michel, H.V., 1980. Extraterrestrial cause for the CretaceousTertiary extinction. Science 208, 1095-1108.

Alvarez, W., Alvarez, L.W., Asaro, F., Michel, H.V., 1982. Current status of the impact theory for the terminal Cretaceous extinction. GSA Special Paper 190, 305-315.

Andruchow-Colombo, A., Escapa, I.H., Cúneo, N.R., Gandolfo, M.A., 2018. Araucaria lefipanensis (Araucariaceae), a new species with dimorphic leaves from the Late Cretaceous of Patagonia, Argentina. American Journal of Botany 105, 1-21.

Ash, S.R., Tidwell, W.D., 1976. Upper Cretaceous and Paleocene floras of the Raton Basin, Colorado and New Mexico. In: Ewing, R.C., and Kues, B.C. (eds) New Mexico Geological Society 27th Field Conference Guidebook. New Mexico Geological Society, Socorrow, pp. 197-203.

Barbour, J.R., 2008. Serenoa repens (Bartr.) Small. In: Bonner, F.T., Karrfait, R.P. (eds) The Woody Plant Seed Manual, 1039-1042.

Barclay, R.S., Johnson, K.R., Betterton, W.J., Dilcher, D.L., 2003. Stratigraphy and megaflora of a K/T boundary section in the eastern Denver Basin, Colorado: Rocky Mountain Geology 3, 45-71.

Bardeen, C.G., Garcia, R.R., Toon, O.B., Conley, A.A., 2017. On transient climate change at the 
Cretaceous-Paleogene boundary due to atmospheric soot injections. Proceedings of the National Academy of Sciences USA 114, 7415-7424.

Barreda, V.D., Cúneo, N.R., Wilf, P., Currano, E.D., Scasso, R.A., Brinkhuis, H., 2012. Cretaceous/ Paleogene floral turnover in Patagonia: drop in diversity, low extinction, and a Classopollis spike. PLoSONE 7, 1-8.

Berry, E.W., 1922. Additions to the flora of the Wilcox Group. USGS Professional Paper 91, 1-20.

Berry, K., 2018a. Paleontological evidence against a major geographic barrier at about the paleolatitude of Colorado, USA, during the Late Campanian (Late Cretaceous): the conspicuous absence of endemic subclades of chasmosaurine ceratopsid (horned) dinosaurs and its significance. The Mountain Geologist 55, 5-18.

Berry, K., 2018b. Icacinaceae in the early middle Paleocene Raton Formation, Colorado. The Mountain Geologist 55, 75-86.

Berry, K., 2019a. Linking fern foliage with spores at the K/Pg boundary section in the Sugarite coal zone, New Mexico, USA, while questioning the orthodoxy of the global pattern of plant succession across the $\mathrm{K} / \mathrm{Pg}$ boundary. Neues Jahrbuch für Geologie und Paläontologie, Abhandlungen 291, 159-169.

Berry, K., 2020. A thelypteridaceous fern from the early Paleocene Raton Formation, south-central Colorado, and its importance in interpreting the climate of the region. The Mountain Geologist 57, 5-20.

Berry, K., in press. The first plants to recolonize western North America following the Cretaceous/Paleogene $(\mathrm{K} / \mathrm{Pg})$ mass-extinction event. International Journal of Plant Sciences 182. DOI: https://doi. org/10.1086/711847

Blonder, B., Royer, D.L., Johnson, K.R., Miller, I., Enquist, B.J., 2014. Plant ecological strategies shift across the Cretaceous-Paleogene boundary. PLoSONE 12, 1-7.

Bowen, M.R., Whitmore, T.C., 1980. A second look at Agathis. CFI Occasional Paper 13, Commonwealth Forestry Institute, Oxford, pp. 1-19.

Britton, M.R., Watkins, J.E., Jr., 2016. The economy of reproduction in dimorphic ferns. Annals of Botany 118, 1139-1149.

Brodribb, T.J., Piterrman, J., Coomes, D.A., 2012. Elegance vs. speed: examining the competition between conifer and angiosperm trees. International Journal of Plant Sciences 173, 673-694.

Brown, R.W., 1962. Paleocene flora of the Rocky Mountains and Great Plains. USGS Professional Paper 375, 1-119.

Brugger, J., Feulner, G., Petri, S., 2017. Baby, it's cold outside: climate model simulations of the effects of the asteroid impact at the end of the Cretaceous. Geophysical Research Letters 44, 419-427.

Carpenter, K.J., 2005. Stomatal architecture and evolution in basal angiosperms. American Journal of Botany 92, 1595-1615.
Carpenter, W.J., 1987. Temperature and imbibition effects on seed germination of Sabal palmetto and Serenoa repens. Horticulture Science 22, 660-661.

Chanderbali, A.S., Van der Werff, H., Renner, S.S., 2001. Phylogeny and historical biogeography of Lauraceae: evidence from the chloroplast and nuclear genomes. Annals of the Missouri Botanical Gardens 88, 104-134.

Chen, Y.-C., Li, C., Zhao, Y.-X., Gao, M., Wang, J.-Y., Liu, K.-W., Wang, K., Wu, Li.-W., Jiao, Y.-L., Xu, Z.-L., He, W.-G., Zhang, Q.-Y., Liang, C.-K., Hsiao, Y.-Y., Zhang, D.-Y., Lan, S.-R., Huang, L., Xu, W., Tsai, W.-C., Liu, Z.-J., Van de Peer, Y., Wang, D.-W., 2020. The Litsea genome and the evolution of the laurel family. Nature Communications 11, 1-14.

Chin, K., Pearson, D., Ekdale, A.A., 2013. Fossil worm burrows reveal very early terrestrial animal activity and shed light on trophic resources after the end-Cretaceous mass extinction. PLoSONE 8, 1-8.

Chiarenza, A.A., Farnsworth, A., Mannion, P.D., Lunt, D.J., Valdes, P.J., Morgan, J.V., Allison, P.A., 2020. Asteroid impact, not volcanism, caused the endCretaceous dinosaur extinction. Proceedings of the National Academy of Sciences, USA, 117, 1708417093.

Christopher, R.A., Prowell, D.C., 2002. A palynological biozonation for the Maastrichtian Stage (Upper Cretaceous) of South Carolina, USA. Cretaceous Research 23, 639-669.

Clarke, R.T., 1963. Palynology of the Vermejo Formation coals (Upper Cretaceous) in the Cañon City coal field, Fremont County, Colorado. Ph.D. Thesis, University of Oklahoma.

Clout, M.N., Tilley, J.A.V., 1992. Germination of miro (Prumnopitys ferruginea) seeds after consumption by New Zealand pigeons (Hemiphaga novaeseelandiae). New Zealand Journal of Botany 30, 25-28.

Crocker, W., 1938. Life-span of seeds. Botanical Review 4, 235-274.

Davies, R., Pritchard, H., 1998. Seed storage and germination of the palms Hyphaene thebaica, $H$. petersiana and Medemia argun. Seed Science and Technology 26, 823-828.

Denk, T., Oh, I.-C., 2006. Phylogeny of Schisandraceae based on morphological data: evidence from modern plants and the fossil record. Plant Systematics and Evolution 256, 113-145.

Dickie, J.B., Smith, R.D., 1995. Observations on the survival of seeds of Agathis spp. stored at low moisture contents and temperatures. Seed Science Research 5, 5-14.

Dickie, J.B., Pritchard, H.W., 2002. Systematic and evolutionary aspects of desiccation tolerance in seeds. In: Black, M., Pritchard, H.W. (eds) Desiccation and Survival in Plants: Drying without Dying. CABI Publications, New York, pp. 239-260.

Dickie, J.B., Balick, M.J., Linington, I.M., 1993. Studies on the practicality of ex situ preservation of palm seeds. Principes 37, 94-98. 
Dorf, E., 1939. Fossil plants from the Upper Cretaceous Aguja Formation of Texas. American Museum Novitates 1015, 1-9.

Duman, J.G., Olsen, T.M., 1993. Thermal hysteresis protein activity in bacteria, fungi, and phylogenetically diverse plants. Cryobiology 30, 322-328.

Ellis, R.H., Hong, T.D., Roberts, E.H., 1990. An intermediate category of seed storage behaviour? I. COFFEE. Journal of Experimental Botany 41, 1167-1174.

El-Soughier, M.I., Mehrotra, R.C., Zhou, Z.-Y., Shi G., 2019. Nypa fruits and seeds from the Maastrichtian-Danian sediments of Bir Abu Minqar, South Western Desert, Egypt. Palaeoworld 20, 75-83.

Escapa, I.H., Iglesias, A., Wilf, P., Catalano, S.A., Caraballo-Ortiz, M.A., Cúneo, N.R., 2018. Agathis trees of Patagonia's Cretaceous-Paleogene death landscapes and their evolutionary significance. American Journal of Botany 105, 1345-1368.

Farnsworth, E., 2000. The ecology and physiology of viviparous and recalcitrant seeds. Annual Review of Ecology and Systematics, 107-138.

Field, D.J., Bercovici, A., Berv, J.S., Dunn, R., Fastovsky, D.E., Lyson, T.R., Vajda, V., Gauthier, J.A., 2018. Early evolution of modern birds structured by global forest collapse at the end-Cretaceous mass extinction. Current Biology 28, 1-7.

Franchi, G.G., Piotto, B., Nepi, M., Baskin, C.C., Baskin, J.M., Pacini, E., 2011. Pollen and seed desiccation tolerance in relation to degree of developmental arrest, dispersal, and survival. Journal of Experimental Botany 62, 5267-5281.

Frederiksen, N.O., 1980. Sporomorphs from the Jackson Group (Upper Eocene) and adjacent strata of Mississippi and Western Alabama. USGS Professional Paper 1084, 1-75.

Futuyma, D.J., 1989. Speciational trends and the role of species in macroevolution. The American Naturalist $134,318-321$.

Greenwood, D.R., West, C.K., 2016. A fossil coryphoid palm from the Paleocene of western Canada. Review of Palaeobotany and Palynology 239, 55-65.

Greenwood, D.R., Wing, S.L., 1995. Eocene continental climates and latitudinal temperature gradients. Geology 23, 1044-1048.

Harley, M.M., 2006. A summary of fossil records for Arecaceae. Botanical Journal of the Linnean Society 151, 39-67.

Hofmann, P., Steiner, A.M., 1989. An updated list of recalcitrant seeds. Landwirtschaftliche Forschung $42,310-323$.

Hong, T.D., Linington, S., Ellis, R.H., 1997. Seed storage behavior: a compendium. Handbook for Genebanks: No. 4. International Plant Genetic Resources Institute, Rome. 104 p.

Huegele, I.B., Manchester, S.R., 2020. An Early Paleocene carpoflora from the Denver Basin of Colorado, USA, and its implications for plant-animal interactions and fruit size evolution. International Journal of Plant Sciences 181, 646-665.

Huggett, R.J., 1998. Fundamentals of biogeography. Routledge, New York, $261 \mathrm{p}$.

Iglesias, A., Wilf, P., Johnson, K.R., Zamuner, A.B., Cúneo, N.R., Matheos, S.D., 2007. A Paleocene lowland macroflora from Patagonia reveals significantly greater richness than North American analogs. Geology 35, 947-950.

Iglesias, A., Artabe, A.E., Morel, E.M., 2011. The evolution of Patagonian climate and vegetation from the Mesozoic to the present. Biological Journal of the Linnean Society 103, 409-422.

Jablonski, D., 2008. Species selection: theory and data. Annual Review of Ecology, Evolution, and Systematics 39, 501-524.

Jaganathan, G.K., Li, J., Yang, Y., Han, Y., Liu, B., 2019. Complexities in identifying seed storage behavior of hard seed-coated species: a special focus on Lauraceae. Botany Letters 166, 1-9.

Johnson, K.R., 1996. Description of seven common fossil leaf species from the Hell Creek Formation (Upper Cretaceous: Upper Maastrichtian), North Dakota, South Dakota, and Montana. Proceedings of the Denver Museum of Natural History 3, 1-48.

Johnson, K.R., 2002. Megaflora of the Hell Creek and lower Fort Union Formations in the western Dakotas: Vegetational response to climate change, the Cretaceous-Tertiary boundary event, and rapid marine transgression. GSA Special Paper 361, 329-391.

Johnson, K.R., Reynolds, M.L., Werth, K.W., Thomasson, J.R., 2003. Overview of the Late Cretaceous, early Paleocene, and early Eocene megafloras of the Denver Basin, Colorado. Rocky Mountain Geology 38, 101-120.

Jud, N.A., Gandolfo, M.A., Iglesias, A., Wilf, P., 2018. Fossil flowers from the early Paleocene, Argentina, with affinity to Schizomerieae (Cunoniaceae). Annals of Botany 121, 431-442.

Kauffman, E.G., Upchurch, G.R., Nichols, D.J., 1990. The Cretaceous-Tertiary boundary interval at south table mountain, near Golden, Colorado. In: Kauffman, E.G., Walliser, O.H. (eds) Extinction Events in Earth History. Lecture Notes in Earth Sciences, vol 30. Springer, Berlin, Heidelberg., pp. 365-392.

Knowlton, F.H., 1930. The flora of the Denver and associated formations of Colorado. USGS Professional Paper 155, 1-142.

Lee, W.T., Knowlton, F.H., 1917. Geology and paleontology of the Raton Mesa and other regions, Colorado and New Mexico. USGS Professional Paper, 101, 1-435.

Leppe, M., Mihoc, M., Varela, N., Stinnesbeck, W., Mansilla, H., Bierma, H., Cisterna, K., Frey, E., Jujihara, T., 2012. Evolution of the Austral-Antarctic flora during the Cretaceous: new insights from a paleobiogeographic perspective. Revista Chilena de Historia Natural 85, 369-392. 
Lesquereux, L., 1873. Lignitic formation and fossil flora. In: Hayden F.V. (ed.) Sixth annual report of the United States Geological Survey of the Territories: Part II. Special reports on geology and paleontology, pp. 315-428.

Li, L., Li, J., Rohwer, J.G., Van Der Werff, H., Wang, Z.-H., and Li, H.-W., 2011. Molecular phylogenetic analysis of the Persea group (Lauraceae) and its biogeographic implications on the evolution of tropical and subtropical amphi-Pacific disjunctions. American Journal of Botany 98, 1520-1536.

Lloyd, R.M., Klekowski, E.J., 1970. Spore germination and viability in Pteridophyta: evolutionary significance of chlorophyllous spores. Biotropica 2, 129-137.

Lyson, T.R., Miller, I.M., Bercovici, A.D., Weissenburger, K., Fuentes, A.J., Clyde, W.C., Hagadorn, J.W., Butrim, M.J., Johnson, K.R., Fleming, R.F., Barclay, R.S., MacCracken, S.A., Lloyd, B., Wilson, G.P., Krause, D.W., Chester, S.G.B., 2019. Exceptional continental record of biotic recovery after the Cretaceous/Paleogene mass extinction. Science 366, 977-983.

Manchester, S.R., 2014. Revisions to Roland Brown's North American Paleocene flora. Acta Musei Nationalis Pragae, Series B - Historia Naturalis 70, 153-210.

Manchester, S.R., Lehman, T.M., Wheeler, E.A., 2010. Fossil palms (Arecaceae, Coryphoideae) associated with juvenile herbivorous dinosaurs in the Upper Cretaceous Aguja Formation, Big Bend National Park, Texas. International Journal of Plant Sciences 171, 679-689.

Matsunaga, K.K.S., Manchester, S.R., Srivastava, R., Kapgate, D.K., Smith, S.Y., 2019. Fossil palm fruits from India indicate a Cretaceous origin of Arecaceae tribe Borasseae. Botanical Journal of the Linnean Society 190, 260-280.

McIver, E.E., 1999. Paleobotanical evidence for ecosystem disruption at the Cretaceous-Tertiary boundary from Wood Mountain, Saskatchewan, Canada. Canadian Journal of Earth Sciences 36, 775-789.

Morgan, J., Artemieva, N., Goldin, T., 2013. Revisiting wildfires at the K-Pg boundary. JGR Geosciences 118, 1508-1520.

Morris, A.B., Bell, C.D., Clayton, J.W., Judd, W.S., Soltis, D.E., Soltis, P.S., 2007. Phylogeny and divergence time estimation in Illicium with implications for New World biogeography. Systematic Botany 32, 236-249.

Nichols, D.J., Brown, J.L., 1992. Palynostratigraphy of the Tullock Member (lower Paleocene) of the Fort Union Formation in the Powder River Basin, Montana and Wyoming. USGS Bulletin 1917, 35 p.

Nichols, D.J., Johnson, K.R., 2002. Palynology and microstratigraphy of Cretaceous-Tertiary boundary sections in southwestern North Dakota. GSA Special Paper 361, 95-143.

Nichols, D.J., Jarzen, D.M., Orth, C.J., Oliver, P.Q., 1986. Palynological and iridium anomalies at
Cretaceous-Tertiary boundary, south-central Saskatchewan. Science 231, 714-717.

Nie, Z.-L., Wen, J., Sun, H., 2007. Phylogeny and biogeography of Sassafras (Lauraceae) disjunct distributions between eastern Asia and eastern North America. Plant Systematics and Evolution 267, 191-203.

Noblick, L.R., Tucker Lima, J.M., Valdes, I.R., 2018. Nypa fruits in the Western Atlantic: potential for recolonization? Palms 62, 175-184.

Offord, C.A., Porter, C.L., Meagher, P.F., Errington, G., 1999. Sexual reproduction and early plant growth of the Wollemi Pine (Wollemia nobilis), a rare and threatened Australian conifer. Annals of Botany $84,1-9$.

Olson, D.F. Jr., Barnes, R.L., Karrfalt, R.P., 2008. Sabal palmetto. In: Bonner, F.T., Karrfalt, R.P. (eds) The Woody Plant Seed Manual. USDA, Washington, D.C., pp. 997-999.

Orozco-Segovia, A., Batis, A.I., Rojas-Aréchiga, M., Mendoza, A., 2003. Seed biology of palms: a review. Palms 47, 79-94.

Orth, C.J., Gilmore, J.S., Knight, J.D., Pillmore, C.L., Tschudy, R.H., Fassett, J.E., 1981. An Ir abundance anomaly at the palynological CretaceousTertiary boundary in northern New Mexico. Science 214, 1341-1343.

Pillmore, C.L., Nichols, D.J., Fleming, R.F., 1999. Field guide to the continental Cretaceous-Tertiary boundary in the Raton Basin, Colorado and New Mexico. GSA Field Guides 1, 135-155.

Pole, M., 2008. The record of Araucariaceae macrofossils in New Zealand. Alcheringa 32, 405-426.

Pole, M., Vajda, V., 2009. A new terrestrial Cretaceous-Paleogene site in New Zealand - turnover in macroflora confirmed by palynology. Cretaceous Research 30, 917-938.

Poole, I., Cantrill, D.J., 2006. Cretaceous and Cenozoic vegetation of Antarctica integrating the fossil wood record. Geological Society of London Special Publication $258,63-82$.

Raymer, J.D., 2010. Cretaceous/Paleogene boundary biostratigraphy and palynofacies of the Alo-1 well, southeastern Nigeria. M.S. Thesis, Missouri University of Science and Technology, $67 \mathrm{p}$.

Raymond, A., Phillips, M.K., Gennett, J.A., Comet, P.A., 1997. Palynology and paleoecology of lignites from the Manning Formation (Jackson Group) outcrop in the Lake Somerville spillway of east-central Texas. International Journal of Coal Geology 34, 195-223.

Reichgelt, T., West, C.K., Greenwood, D.R., 2018. The relation between global palm distribution and climate. Scientific Reports 8, 1-11.

Renne, P.R., Arenillas, I., Arz, J.A., Vajda, V., Gilabert, V., Bermúdez, H.D., 2018. Multi-proxy record of the Chicxulub impact at the Cretaceous-Paleogene boundary from Gorgonilla Island, Colombia. Geology 46, 547-550.

Roberts, E.H., 1973. Predicting the storage life of seeds. Seed Science and Technology 1, 499-514. 
Robertson, D.S., Lewis, W.M., Sheehan, P.M., Toon, O.B., 2013. K-Pg extinction patterns in marine and freshwater environments: the impact winter model. Journal of Geophysical Research: Biogeosciences 118, 1006-1014.

Romero, E., Amenábar, C.R., Zamaloa, M.C., Concheyro, A., 2019. Nothofagus and the associated palynoflora from the Late Cretaceous of Vega Island, Antarctica Peninsula. Polish Polar Research 40, 227-253.

Rothwell, G.W., Stockey, R.A., 1991. Onoclea sensibilis in the Paleocene of North America, a dramatic example of structural and ecological stasis. Review of Palaeobotany and Palynology 70, 113-124.

Royer, D.L., Sack, L., Wilf, P., Lusk, C.H., Jordan, G.H., Niinemets, U., Wright, I.J., Westoby, M., Cariglino, B., Coley, P.D., Cutter, A.D., Johnson, K.R., Labandeira, C.C., Moles, A.T., Palmer, M.B., Valladares, F., 2007. Fossil leaf economics quantified: calibration, Eocene case study, and implications. Paleobiology 33, 574-589.

Sato, T., 1982. Adaptation to cold climate of ferns native to Hokkaido with reference to the alternation of generations. In: Li, P.H., Sakai, A. (eds) Plant Cold Hardiness and Freezing Stress: Mechanisms and Crop Implications 2, Academic Press, Inc., New York, pp. 447-458.

Shen-Miller, J., 2002. Sacred lotus, the long-living fruits of China Antique. Seed Science Research 12, 131-143.

Shen-Miller, J., Mudgett, M.B., Schopf, J.W., Clarke, S., Berger, R., 1995. Exceptional seed longevity and robust growth: ancient Sacred Lotus from China. American Journal of Botany 82, 1367-1380.

Smiskova, A., Vlasinova, H., Havel, L., 2005. Somatic embryogenesis from zygotic embryos of Schisandra chinensis. Biologia Plantarum 49, 451-454.

Snedaker, S.C., Getter, C.D., 1985. Coasts: coastal resources management guidelines. USDI, 205 p.

Spicer, R.A., 1989. Plants at the Cretaceous-Tertiary boundary (and discussion). Philosophical Transactions of the Royal Society of London, Series B, Biological Sciences 325, 291-305.

Spicer, R.A., Collinson, M.E., 2014, Plants and floral change at the Cretaceous-Paleogene boundary: three decades on. GSA Special Paper 505, 117-132.

Srivastava, R., Srivastava, G., Dilcher, D.L., 2014. Coryphoideae palm leaf fossils from the Maastrichtian-Danian of central India with remarks on the phytogeography of the Coryphoideae (Arecaceae). PLOSONE 9, 1-10.

Stiles, E., Wilf, P., Iglesias, A., Gandolfo, M.A., Cúneo, N.R., 2020. Cretaceous-Paleogene plant extinction and recovery in Patagonia. Paleobiology 47, 1-25.

Stone, J.F., 1973. Palynology of the Almond Formation (Upper Cretaceous) Rock Springs Uplift, Wyoming. Bulletins of American Paleontology 64, 1-136.

Su, T., Farnsworth, A., Spicer, R.A., Huang, J., Wu, F.-X., Liu, J., Li, S.-F., Wing, Y.-W., Huang, Y.-J.,
Deng, W.-Y.-D., Tang, H., Xu, C.-L., Zhao, F., Srivastava, G., Valdes, P.J., Deng, T., Zhou, Z.-K., 2019. No high Tibetan Plateau until the Neogene. Science Advances 5, 1-8.

Subbiah, A., Ramdhani, S., Pammenter, N.W., Macdonald, A.H.H., Sershen, 2019. Towards understanding the incidence and evolutionary history of seed recalcitrance: an analytical review. Perspectives in Plant Ecology, Evolution, and Systematics 37, 11-19.

Tabor, C.R., Bardeen, C.G., Otto-Bliesner, B.L., Garcia, R.R., Toon, O.B., 2020. Causes and climatic consequences of the impact winter at the Cretaceous-Paleogene Boundary. Geophysical Research Letters 47, 1-10.

Takahashi, M.K., Horner, L.M., Kubota, T., Keller, N.A., Abrahamson, W.G., 2011. Extensive clonal spread and extreme longevity in saw palmetto, a foundation clonal plant. Molecular Ecology 18, 3730-3742.

Tiffney, B.H., Manchester, S.R., 2001. The use of geological and paleontological evidence in evaluating phylogeographic hypotheses in the Northern Hemisphere Tertiary. International Journal of Plant Sciences 162, S3-S17.

Tommasi, F., Paciolla, C., de Pinto, M.C., Gara, L.D., 2006. Effects of storage temperature on viability, germination and antioxidant metabolism in Ginkgo biloba L. seeds. Plant Physiology and Biochemistry 44, 359-368.

Toon, O.B., Pollack, J.B., Ackerman, T.P., Turco, R.P., McKay, C.P., Liu, M.S., 1982. Evolution of an impact-generated dust cloud and its effects on the atmosphere. GSA Special Paper 190, 187-200.

Tredici, P.D., 1992. Natural regeneration of Ginkgo biloba from downward growing cotyledonary buds (basal chichi). American Journal of Botany 79, 522-530.

Tschudy, R.H., 1970. Two new pollen genera (Late Cretaceous and Paleocene) with possible affinity to the Illiciaceae. USGS Professional Paper 643-F, 1-13.

Tschudy, R.H., Tschudy, B.D., 1986. Extinction and survival of plant life following the Cretaceous/ Tertiary boundary event, Western Interior, North America. Geology 14, 667-670.

Tschudy, R.H., Pillmore, C.L., Orth, C.J., Gillmore, J.S., Knight, J.D., 1984. Disruption of the terrestrial plant ecosystem at the Cretaceous-Tertiary boundary, Western Interior. Science 225, 1030-1032.

Tweddle, J.C., Dickie, J.B., Baskin, C.C., Baskin, J.M., 2003. Ecological aspects of seed desiccation sensitivity. Journal of Ecology 91, 294-304.

Upchurch, G.R., Jr., 1995. Dispersed angiosperm cuticles: their history, preparation, and application to the rise of angiosperms in Cretaceous and Paleocene coals, southern Western Interior of North America. International Journal of Coal Geology 28, 161-227.

Upchurch, G.R., Jr., Askin, R.A., 1990. Latest Cretaceous and earliest Tertiary dispersed plant cuticles from Seymour Island, Antarctica. Antarctic Journal of the U.S. (1989 Review) 24, 7-10. 
Upchurch, G.R., Jr., Lomax, B.H., Beerling, D.J., 2007. Paleobotanical evidence for climate change across the Cretaceous-Tertiary boundary, North America: 20 years after Wolfe and Upchurch. Cour ForschInst Senckenberg 258, 57-74.

Vajda, V., Bercovici, A., 2012. Pollen and spore stratigraphy of the Cretaceous-Paleogene mass-extinction interval in the Southern Hemisphere. Stratigraphy $36,153-164$

Vajda, V., Bercovici, A., 2014. The global vegetation pattern across the Cretaceous-Paleogene mass extinction interval: a template for other mass extinction events. Global and Planetary Change 122, 29-49.

Vajda, V., McLoughlin, S., 2004, Fungal proliferation at the Cretaceous-Tetiary boundary. Science 303, 1489.

Vajda, V., McLoughlin, S., 2007, Extinction and recovery patterns of vegetation across the CretaceousPaleogene boundary - a tool for unraveling the causes of the end-Permian mass extinction. Review of Palaeobotany and Palynology 144, 99-112.

Vajda, V., Ocampo, A., Ferrow, E., Bender Koch, C., 2015. Nanoparticles as the primary cause for longterm sunlight suppression at high southern latitudes following the Chicxulub impact. Gondwana Research 27, 1079-1088.

Vallati, P., Sosa Tomas, A.D., Casal, G., 2020. A Maastrichtian terrestrial palaeoenvironment close to the K/Pg boundary in the Golfo San Jorge basin, Patagonia, Argentina. Journal of South American Earth Sciences 97, 1-11.

Villegente, M., Marmey, P., Job, C., Galland, M., Cueff, G., Godin, B., Rajou, L., Balliau, T., Zivy, M., Fogliani, B., Sarramegna-Burtet, V., Job, D., 2017. A combination of histological, physiological, and proteomic approaches shed light on seed desiccation tolerance of the basal angiosperm Amborella trichopoda. Proteomes 5, 1-16.

Vrba, E.S., Gould, S.J., 1986. The hierarchical expansion of sorting and selection: sorting and selection cannot be equated. Paleobiology 12, 217-228.
Whitmore, T.C., 1980. Utilization, potential, and conservation of Agathis, a genus of tropical Asian conifers. Economic Botany 34, 1-12.

Wilf, P., Johnson, K.R., 2004. Land plant extinction at the end of the Cretaceous: a quantitative analysis of the North Dakota megafloral record. Paleobiology 30, 347-368.

Wilf, P., Johnson, K.R., Huber, B.T., 2003. Correlated terrestrial and marine evidence for global climate changes before mass extinction at the CretaceousPaleogene boundary. PNAS 100, 599-604.

Wolfe, J.A., 1975. Some aspects of plant geography of the Northern Hemisphere during the Late Cretaceous and Tertiary. Annals of the Missouri Botanical Garden 62, 264-279.

Wolfe, J.A., 1987. Late Cretaceous-Cenozoic history of deciduousness and the terminal Cretaceous event. Paleobiology 13, 215-226.

Wolfe, J.A., 1997. Relations of environmental change to angiosperm evolution during the Late Cretaceous and Tertiary. In: Iwatsuki, K., Raven, P.H. (eds) Evolution and the Diversification of Land Plants. Springer-Verlag, Tokyo, pp. 269-290.

Wolfe, J.A., Upchurch, G.R., Jr., 1987. Leaf assemblages across the Cretaceous-Tertiary boundary in the Raton Basin, New Mexico and Colorado. Proceedings of the National Academy of Sciences, USA 84, 5096-5100.

Wood, C.B., Vautier, H.J., Bin, W., Rakotondranony, L.G., Pritchard, H.W., 2006. Conservation biology for seven palm species from diverse genera. Aliso $22,278-284$.

Wyse, S.V., Dickie, J.B., 2017. Predicting the global incidence of seed desiccation sensitivity. Journal of Ecology 107, 1082-1093.

Zona, S., 1990. A monograph of Sabal. Aliso: A Journal of Systematic and Evolutionary Botany 12, 583-666. 